\title{
THE MORBID ANATOMY AND PATHOLOGY
}

or

\section{DR. BRADSHAW'S CASE}

\section{OF \\ MYELOPATHIC ALBUMOSURIA}

BY

THOS. R. BRADSHAW, B.A., M.D., M.R.C.P.

SENIOR ASSISTANT PHYSICIAN TO THE LIVERPOOL ROYAL INFIRMARY

AND

W. B. WARRINGTON, M.D., M.R.C.P.

DEMONSTRATOR OF PATHOLOGY IN UNIVERSITY COLLEGE, LIVERPOOL;

ASSISTANT PHYSICIAN TO THE HOSPITAL FOR CONSUMPTION AND DISEASES OF THE CHEST

Received January 24th-Read March 14th, 1899.

ON the 26th of April, 1898, one of us (Dr. Bradshaw) read before this Society an account of a case in which the urine contained a very large quantity of a form of proteid which was shown by its chemical reactions to be related to the class of bodies known as albumoses (1). The main facts of the case which were then reported, and its subsequent history until the death of the patient, were briefly as follows.

A man, 70 years of age, a respectable shopkeeper in voL. LXXXII. 
Liverpool, noticed about the end of the year 1896 that he passed milky urine from time to time. In August, 1897, systematic examinations of the urine were instituted, and it was found that it always contained a large but variable amount of a proteid body which was coagulated by a temperature below $60^{\circ}$ centigrade and yielded other reactions which served to identify it with the peculiar albuminous body which was first described by Bence Jones in 1847, and is now commonly known as albumose (2).

Beyond the fact of the presence of this remarkable body in the urine there was at first nothing to suggest that the patient was the subject of any serious disease. All the ordinary indications of renal disorder were wanting, and for some months there was nothing in his circumstances or condition which afforded any clue to the significance of the remarkable condition of the urine. An examination of the literature, however, showed that the kind of albumosuria described by Bence Jones had been observed in six cases in all, and that in every instance it had been found to be associated with an affection of the bones of the trunk. This affection had been at first regarded as a form of osteomalacia, but the more recent observers had found that it was a form of multiple myeloma, a disorder in which the bones undergo absorption, and become attenuated in consequence of the development of a new growth which originates in the marrow spaces and spreads outwards, causing absorption of the hard parts of the bone. In the few instances in which albumosuria had been found in connection with multiple myeloma, the existence of the latter had only been recognised on the post-mortem table, it had never been suspected during the patient's life; but the records of these cases led Dr. Bradshaw to suspect that this might be a case of multiple myeloma, aud to watch carefully for the advent of local indications of bone disease. This suspicion was strengthened when, near the close of 1897 , the patient complained of severe pains and tenderness 
about the ribs, sternum, and back, and it became almost a certainty when, early in 1898 , there appeared obvious signs of diminished rigidity of the bones, consisting of an unnatural yielding of the chest walls to the pressure of the hand or the stethoscope, curvature of the spine, and subsequently spontaneous fractures of the ribs. During the progress of the case there were remarkable remissions in the intensity of the symptoms, both local and general. In January, 1898, the patient was unable to leave his bed on account of the pains, and suffered from a severe attack of bronchitis, followed in February by pneumonia affecting one lung and accompanied by rusty sputum. For some days he seemed to be in extremis. After this he gradually improved; the pains subsided almost entirely, the lungs cleared up, and in the spring he went to reside with friends in Cheshire, and for two or three months was able to get up and down the stairs and to take short walks out of doors. About the middle of July the pains returned with great intensity, and he was unable to leave his bed; deafness was noticed on one side, uncontrollable vomiting came on, and he died apparently from exhaustion on August 10th. The peculiar character of the urine persisted till the end, but a specimen passed a few days before the fatal issue contained a little albumin in addition to the large quantity of albumose.

Owing to the death having taken place in a private house some valuable time was lost before arrangements could be made for removing the remains to a mortuary and holding an autopsy. A limited examination only was permitted, but it was amply sufficient to confirm the diagnosis made during life.

The following are the chief points of the necropsy, which was made by us fifty-nine hours after death. 'There were also present Dr. James Barr, Mr. W. T. Thomas, and several other practitioners who were interested in the case.

Externally there were no indications of decomposition. Rigor mortis was present. On removing the integu- 
ment from the thorax a small quantity of subcutaneous fat was found.

The whole bony framework of the thorax, the sternum, ribs, and vertebræ, presented a striking departure from the normal. The bones were so brittle that they could be broken by a slight pressure with the finger, a condition more noticeable in some spots than in others, and there were several complete fractures which had doubtless occurred during life. On the right side the sixth rib was found broken across about three inches from its cartilage, and there was an incomplete fracture of the seventh rib in a corresponding situation. The eighth rib presented a slight irregularity which seemed to be due to a fracture which had united. On the left side the fifth and sixth ribs were broken about half an inch from their cartilages.

The change was very pronounced in the sternum, which broke while it was being removed. The gladiolus contained a large irregular cavity filled with a red mass resembling splenic pulp, which was easily squeezed out by slight pressure on the bone. This cavity corresponded to the position of a spot of great tenderness, which had been especially noticed several months before death.

There was a remarkable backward curve of the dorsal spine, and projection forward of the lumbar vertebræ and the promontory of the sacrum, constituting an extreme exaggeration of the normal curves. The degree of the curvature in the dorsal region was roughly measured by drawing a chord from the front of the body of the seventh cervical vertebra to that of the fourth lumbar. The body of the ninth dorsal vertebra, where the backward projection was greatest, was two inches behind this line.

The body of the seventh dorsal vertebra was removed; it was soft enough to be easily cut with the knife. The cut surface felt soft, and presented a disintegrated appearance not unlike that of splenic pulp. 
The organs presented no striking abnormality. Those in the thorax were in their usual position; the pleuræ were free except for some slight adhesions at the apex; the right contained about one ounce of blood-stained serum, the left about two fluid drachms. There was no fluid in the pericardium. The lungs were normal, the heart weighed $8 \frac{1}{2}$ ounces; the right auricle contained a partly decolourised clot; the tricuspid orifice admitted three fingers. The left auricle was normal ; the mitral orifice admitted two fingers; the valve appeared to be competent, but the curtains were thickened; the aortic valve was competent, and to all appearance healthy; there was slight atheroma at the beginning of the aorta.

Post-mortem changes were much advanced in the abdominal organs, especially the pancreas. The liver weighed 37 ounces, its surface was normal; there was no fatty change in its substance and no secondary growths; the hilum was free; the gall-bladder was filled with bile, and there were no gall-stones. The stomach, intestines, and spleen were to all appearance normal.

The right kidney weighed $2 \frac{1}{2}$ ounces. The capsule was rather too adherent, and on removal showed a whitishyellow cortex mottled by distended capillaries. At the upper end a cyst the size of a hazel-nut was found, containing a glairy greenish fluid. At the lower end there was a similar cyst about the size of a pea. The cortex was much diminished, the pyramids were very white, the blood-vessels were not very obvious. On transverse section the outer third of the organ was seen to be occupied by a denser material of a yellowish-white colour. The left kidney weighed $3 \frac{1}{2}$ ounces. On section it resembled the right, but the departures from the normal were less apparent. On the convexity there was a cyst the size of a hazel-nut. The appearance of the organs led us to suppose that they. were able to perform their functions fairly well until the death of the subject.

No enlarged glands were found anywhere, nor were 
any tumours observed either attached to bones or in any part of the body.

A piece of the upper end of one tibia was sawn off. It appeared to be quite normal.

An examination of the head was not allowed.

The material reserved for further examination consisted of a piece of a rib, of a dorsal vertebra, and of the sternum, some of the gelatinous marrow-like substance in the sternum, and pieces of kidney.

On the same day some of the fresh marrow-like substance was extracted with a weak sodium chloride solution. The extract gave a marked albumose reaction with nitric acid and a turbidity with hydrochloric. Unfortunately the rest of the marrow-like material was by inadvertence placed in weak formalin solution, with the result that the proteids were rendered insoluble, and so their coagulation points could not be taken. As far as it went, the evidence pointed to the soft material in the bones containing the same substance as was found in the urine.

The piece of rib exhibited, preserred in formulin, shows that the bone is reduced to a mere shell about the thickness of note-paper, but its general outline is preserved. The interior is occupied by soft material, which in the fresh state was a bluish-red semi-solid pulp which had taken the place of all except the most superficial parts of the bone (Pl. V, fig. 1).

A small piece of rib, freed as far as possible from periosteum and other soft material, and dried in an incubator, was sent to Mr. Collingwood Williams, the Liverpool city analyst, who kindly undertook the analysis of it for us.

His report is as follows:

The quantity available for analysis was 0.117 gramme.

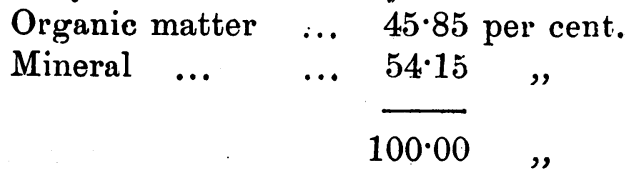


Plate V:

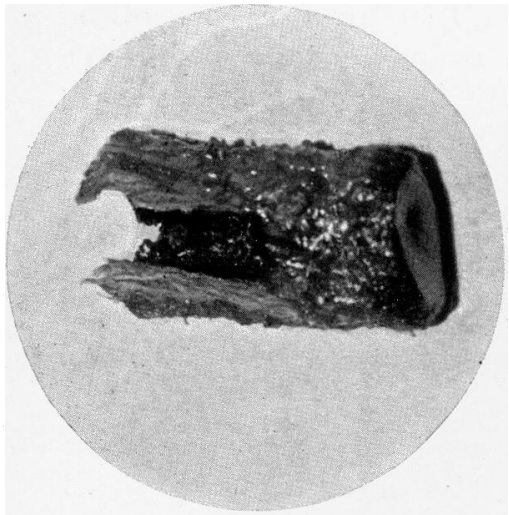

FIG. I.
Med. Chir. Trans., Vol. LXXXII.

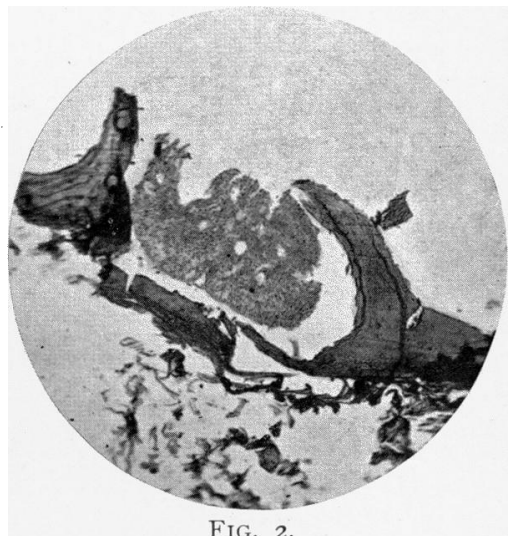

FIG. 2.

F16. I.-A portion of an affected rib near its cartilage. To the right is seen the cartilage in transverse section; to the left is seen the thin shell of bone, part of which has been removed so as to show the contained mass of new growth, which has shrunken somewhat and appears dark. (Nearly natural size.)

Fig. 2.--Transverse section of decalcified rib. The osseous tissue is greatly reduced in thickness, and is being invaded by the new growth which is seen in situ. (Zeiss obj. A without ocular.)

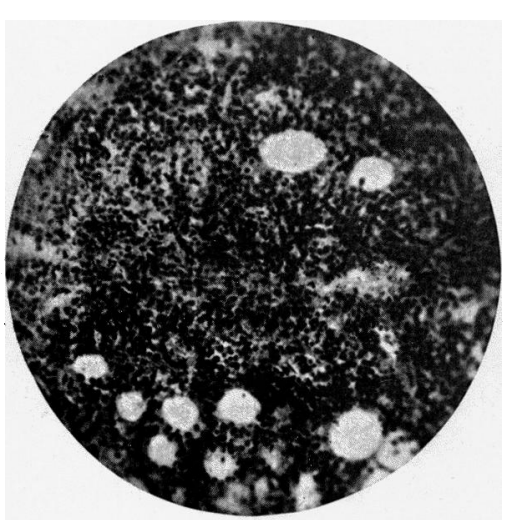

FIG. 3.

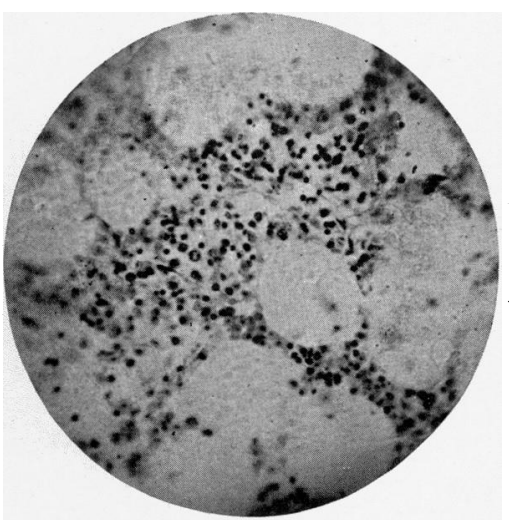

FIG. 4.

FIG. 3. - Section of new growth in interior of sternum. The general characters of the structure are those of a round-celled sarcoma. ( $\frac{1}{5}$ inch objective.)

Fig. 4.-The same as Fig. 3, more highly magnified, showing the cells of the growth in more detail.

(Apochromatic $3 \mathrm{~mm}$. immersion objective, aperture r.40, compensating ocular I2.) 
DR. BRADSHAW'S CASE OF MYELOPATHIC ALBUMOSURIA 257

Composition of ash :

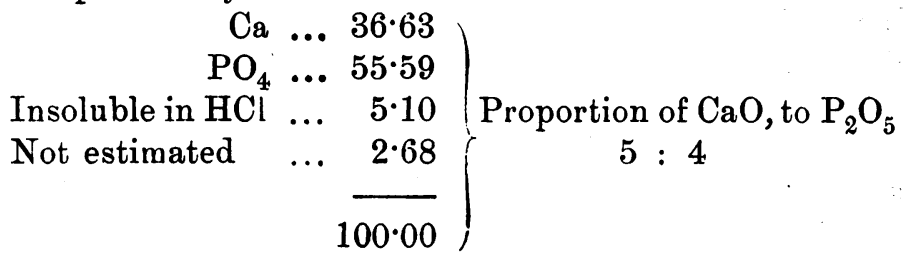

If we make due allowance for the fact that no special precautions were taken to remove the fat, the proportion of organic to inorganic constituents does not depart greatly from the normal.

\section{Microscopical Examination.}

The length of time which had elapsed since the death of the patient made the histological examination in some respects less satisfactory than we should have wished.

A piece of rib was preserved in 4 per cent. formol solution, and portions of the gladiolus and the vertebra in Müller's fluid.

Thin slices of the dried bones were kindly prepared for us by Mr. J. A. Woods, L.D.S., and were mounted in Canada balsam.

The gelatinous marrow-like substance.-This was studied by means of cover-slip preparations fixed with absolute alcohol and ether, and stained in various ways, viz. methylene blue, eosin, and logwood and eosin; and also in sections, - part of the material was fixed by saturated solution of perchloride of mercury, part in Müller's fluid, hardened in alcohol, and embedded and cut in paraffin. The sections were then stained by the above-named dyes, and also by picro-carmine and borax-carmine.

The marrow-like substance was also studied in situ in sections of the bone which had been decalcified by means of a solution of phloroglucin in 5 per cent. nitric acid.

By these means it was found that the cancellous spaces of the ribs, sternum, and vertebra were densely packed 
by a round-celled growth. This growth invaded the bones along the vascular channels, which were considerably dilated, so that islets of bone appeared embedded in the mass of cells.

The cells were almost entirely of the lymphoid variety, a single large nucleus being alone visible in the majority.

A few oval or spindle cells were seen infrequently, but no myeloplaques or eosinophile cells were found. Red blood-corpuscles appeared in considerable numbers, but were never observed to be nucleated. In addition to the lymphocytal form of cell, larger cells with a considerable amount of protoplasm and either a single, double, or reniform nucleus were met with (Pls. V and VI, figs. 2, 7 and 8).

The cover-glass preparations showed the same general features, including the absence of myeloplaques and eosinophile cells, but owing to the presence of fatty and albuminous material they were less satisfactory than the sections.

The Bone.-The decalcified bone of the sternum and vertebra showed normal features, there was no transformation of bone into a lower type of connective tissue, such as has been observed in undoubted cases of osteomalacia, and there was an entire absence of osteoclasts. Dry preparations of these bones likewise showed a normal structure. On the other hand, in the rib, the delicate bony shell, which was cut in transverse section, appeared to have undergone retrograde changes; the normal lacunæ and canals were feebly represented, and where present were irregular in shape and distribution. On the inner surface they seemed to have entirely disappeared, and that part of the bone had a fibrous, and at the same time dotted structure, strongly suggestive of a reversion to a fibrous connective tissue. Indeed, the recognition of the tissue as bone would not have been easy had the facts of the case not been already known (Pl. V, fig. 5).

Owing to the thinness of the bony shell it was impossible to prepare a dry transverse section of the rib so as to compare the inner and outer parts. A dry tangential 


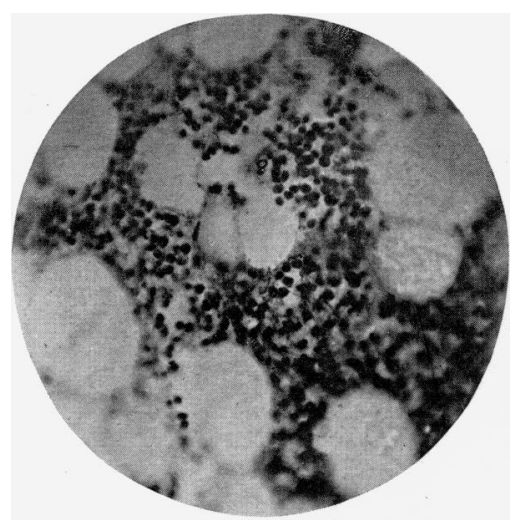

FiG. 5 .

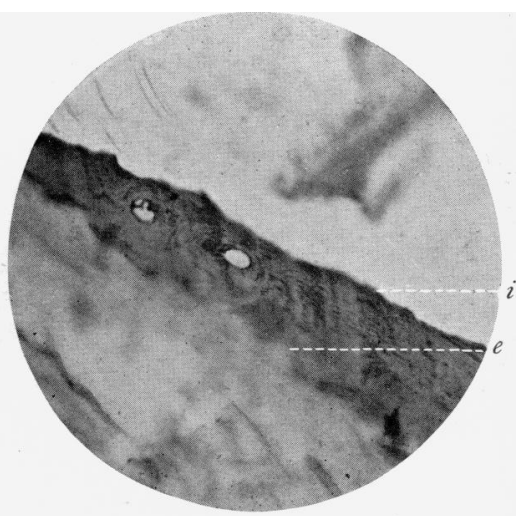

FIG. 6.

FIG. 5. - The same as Fig. 4, another part of Section.

FIG. 6.-Transverse section of decalcified bony shell of rib.

(i) Inner aspect of shell, in contact with new growth which has become detached during manipulation.

(e) External surface, with muscle attached. This section gave some evidence of a retrograde change in the structure of the bone. ( $\frac{1}{5}$ inch objective.)

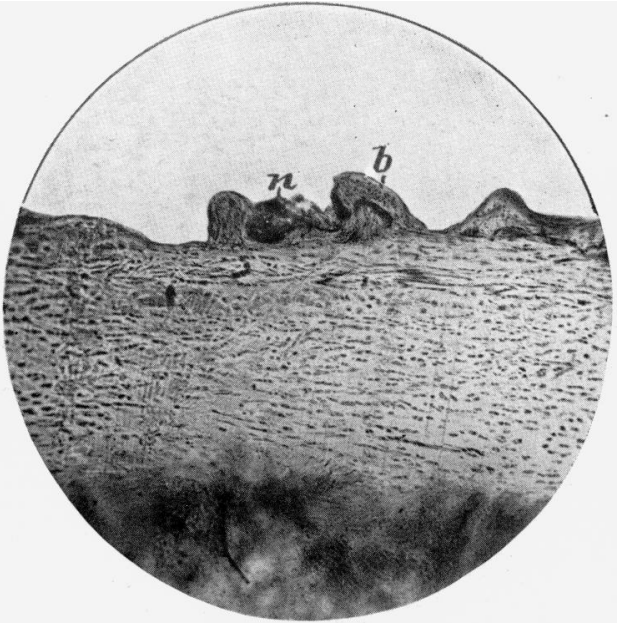

FIG. 7 .

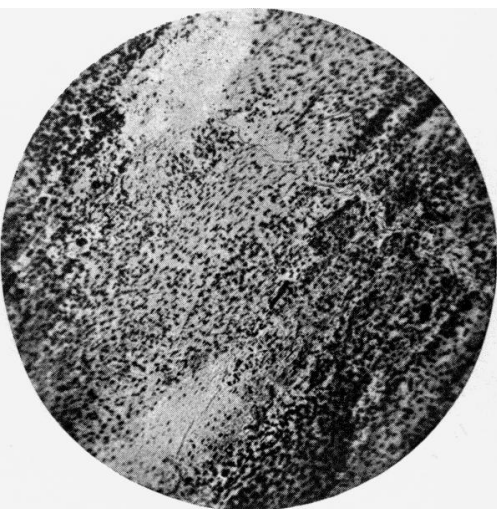

FIG. 8.

FIG. 7.-Transverse section of superficial layer of decalcified sternum.

(b) Internal surface of osseous layer, apparently undergoing erosion.

(n) Fragment of new growth in situ. (Zeiss obj. A without ocular.)

FIG. 8.-Tangential section of dried bony shell of rib, prepared by grinding. Shows normal disposition of lacunæe amd canaliculi. (Zeiss obj. A zuithout ocular.) 
section showed a perfectly normal arrangement of lacunæ and canaliculi (Pl. VI, fig. 6).

Kidneys.-The microscopic appearance was practically that met with in the milder forms of chronic interstitial nephritis ; the connective tissue showed at places proliferation, and the cells of the tubules were found to be in a granular degenerated state, and occasionally lying free in the lumen.

Summary of the morbid anatomy.-As far as the limited examination which was permitted enabled us to ascertain, the characteristic lesions were confined to the bones of the trunk, but it is possible that the cranial bones were affected in a similar way. These lesions consisted in a disappearance of the osseous tissue, beginning centrally, and the growth in its place of a soft vascular mass of undifferentiated round cells. The remaining osseous tissue of the rib appears to have undergone retrograde changes, but that of the other bones shows normal characteristics, from which we infer that the primary lesion was the invasion by the cellular growth. There is no evidence to suggest the existence at any time of primary disease of the kidneys, the changes found in these organs being such as can be accounted for by the irritation arising from the passage through them of the abnormal material which they excreted for many months.

It is obvious that the histological characters of the growth in the interior of the bones merely show that it consists of embryonic cells which have undergone little or no differentiation, and are separated by a very small amount of intercellular substance. It might, therefore, be regarded anatomically either as a round-celled sarcoma, a lymphoma, or a granuloma. Clinically, its progressive development and fatal issue seem to entitle it to rank with the malignant neoplasms, but it differs from them in remaining strictly limited to one kind of structure, and not spreading either to contiguous parts or to distant organs. The cellular mass has originated apparently in the cancellous tissue or marrow spaces of the ribs, sternum, 
and vertebræ, and by its proliferation has caused absorption of the earthy salts and the proper tissue of the bone.

When we come to consider the pathological relationship of this condition we find that, apart from rickets, which only affects the growing bone, cases of extreme flexibility and brittleness of bone fall into two great divisions. On the one hand we have those in which the essential pathological change is a simple absorption of the earthy salts, the Halisteresis Ossium of some authors, a process which, when it affects the skeleton as a whole, constitutes the disease known as osteomalacia or mollities ossium. On the other hand, we have the cases in which absorption of the hard parts of the bone is due to its invasion by some kind of new growth, a condition which, when it occurs locally, is familiar to surgeons as myeloid sarcoma.

Within the last quarter of a century pathologists have come to recognise a more or less generalised absorption of the bones, arising from the simultaneous development of new growths in the bones in various parts of the body. This condition was first described as a distinct disease in 1873 by von Rustizky of Kiew (3), under the name of rultiple myeloma, a designation under which several cases of multiple bone tumours have been recorded since. There can be no doubt that cases of multiple nyeloma have been confounded with osteomalacia. The differential diagnosis between the two diseases is probably not always possible during life, but as a rule their clinical pictures are sufficiently distinct. Osteomalacia is almost confined to young women, often coming on in connection with preguancy. All parts of the body are implicated, the extremities in a marked degree, with the result that the patient is soon confined to bed. The bones are often bent into most fantastic shapes, but actual fractures are few. Multiple mseloma, on the contrary, mostly occurs in men in the latter half of life, the bones of the thorax are those chiefly affected, the patient is able to leave his bed until near the end, deformities are not extreme, and fractures are common. 
We have compared the microscopic sections in our case with sections from a case of undoubted mollities ossium which occurred in the Liverpool Royal Infirmary in 1880 (4). The sections were made by Mr. F. T. Paul, who has kindly placed them at our disposal. In our case, as we have already shown, the interior of the bone is occupied by a cellular mass which is invading the hard parts. In Mr. Paul's specimens the cavities of the bone are occupied by what seems to be marrow, judging from the presence of large myeloplaques, and around this we find a layer of dense fibrous tissue, which seems to represent the bony tissue from which the salts have been removed. Briefly stated, it appears that in osteomalacia the bones are softened owing to loss of earthy salts ; in multiple myeloma the osseous tissue is atrophied without any obvious change in its chemical composition. In the one case the bones bend, in the other they break.

The morbid anatomy of multiple tumours in the bones differs in different cases, and the records leave us uncertain whether the descriptions of multiple myeloma may not refer to two or more varieties of disease. There is, however, one circumstance which serves to differentiate these cases of bone disease into two distinct categories, namely, that some were attended by albumosuria and some were not.

In this communication we will confine ourselves to cases in which albumosuria was observed, and of these only six well-attested instances were on record when the present case was first communicated to this Society in April last year. The leading features of these cases will now be considered.

I. Macintyre's and Bence Jones's case (5). A A description of the urine was communicated to the Royal Society by Bence Jones in 1847, and the whole case was brought before the Royal Medical and Chirurgical Society by Dr. Macintyre in 1850.

A man 45 sears of age suffered from excruciating pains in the chest, back, and loins for upwards of a year. 
The progress of the disease was not uniform, but striking temporary improvement was noticed from time to time. There was tenderness on percussing the chest, but no deformity was observed. The urine contained the albuminous body which we now call albumose, and gave reactions which had never been recognised before, but which were described in detail in the paper read before this Society last April, and need not now be repeated. There was no suspicion during life that the bones were the seat of any morbid affection.

At the post-mortem examination all the ribs were found to be soft and brittle. They could be readily cut with a knife, and could be broken by a very moderate amount of force.' Their interior was charged with a gelatiniform substance of a blood-red colour and unctuous feel. The sternum and the bodies of the vertebræ were similarly affected, but the bones of the extremities were not affected, and the kidneys were healthy.

The microscopical examination of two lumbar vertebræ and a rib was made by $\mathrm{Mr}$. Dalrymple, whose description corresponds very closely with our case (6). He says, "The disease appears to have commenced in the cancellated structure of the bone, for the external osseous laminæ are firmer and more healthy than the internal. The external are still hard, requiring the exertion of some force to cut them ; they are thin, however, and when sliced expose large cancellous cavities filled with a red gelatiniform substance, threaded here and there by fine bony fibres." The bulk of the gelatiniform tissue was composed of nucleated cells, but there were also present granular matter, oil globules, fat cells, caudate cells, and blood-cells. It is worth noting that there is no mention of multinuclear myeloid cells. The condition was regarded as a form of mollities ossium; but $\mathrm{Mr}$. Dalrymple makes the shrewd remark that it bears some resemblance to a malignant disease of the bone, and in the light of subsequent research we shall hardly be wrong in concluding that this was in reality a case of multiple myeloma. 
DR. BRADSHAW'S CASE OF MYELOPATHIC ALBUMOSURIA 263.

II. The second case, Kühne's (7), observed in 1867, was: that of a man aged 40, whose urine contained the body described by Bence Jones. Deformities and other indications of an affection of the bones of the trunk were observed during life, and the diagnosis of osteomalacia was made; but no post-mortem examination was obtained.

III. The next case, which was investigated by Kahler (8) and Huppert, was that of a medical man who died in 1887 at the age of 54, having been ill about eight years. The symptoms were, for the most part, pain and tenderness, and, later, deformities in the bones of the trunk. Albumose was recognised in the urine for six years before the fatal termination.

The post-mortem examination showed the existence of softening of the ribs, sternum, and vertebræ. Microscopically the condition was found to be :-extreme osteoporosis with formation of numerous Howship's lacunæ, determined by the multiple proliferation of a tissue consisting of rather large round cells (round-celled sarcoma, so-called myeloma).

In this case several bony tumours were found in connection with various affected bones.

Kahler's paper contains an exact clinical picture of the case. The diagnosis made during life was osteomalacia, but the author suggests that the occurrence of albumosuria might in future serve to distinguish multiple inyeloma from osteomalacia.

IV. The next case was under the care of Strkvis of Amsterdam, and was published in 1891 (9). There was albumosuria but no indication of bone affection during life. After death, however, the bones were found highly brittle, and the place of the marrow was taken by a red gelatinous mass.

There were also in the connective tissue, the muscles, the periosteum, and the serous membranes numerous dry firm tumours of yellowish-white colour. Unfortunately no microscopical examination was made, and it is quite possible that the tumours scattered about the body had 
nothing to do with the growth in the bones. In this case it is stated that the humerus was affected. The kidneys contained some chalky deposits, but appeared to be normal in other respects.

V. The next case was observed in the clinic of Stintzing of Jena in 1895 (10). The patient was a man aged 61 , who presented marked deformity, the back being in a position of extreme kyphosis, and the head sunk between the shoulders. Pains in the back and the chest were severe. The urine was investigated with great care by Professor Matthes (11) of Jena, who came to the conclusion that the albumose which was present was really a body distinct from digestive albumoses, and indeed fron all other bodies known to chemistry. The diagnosis made during life was osteomalacia. The post-mortem showed that there was extreme softening of the bones confined to the trunk, the enlarged marrow spaces being occupied by a dark bluish-red soft tissue. Microscopic examination of a piece of affected rib gave the following result :

The compact tissue was wanting in places. Where it, was present it was very much thinned, and contained numerous wide, irregular lacunæ, filled with a vascular. spindle-celled tissue. Beneath the compact tissue, and replacing it where it was wanting, was a zone of tissue consisting of closely packed round cells, intersected by irregularly running bands of spindle-cells. It was of unequal thickness, and projected unevenly into th. marrow. In it were some rather large islets of cartilage and numerous necrotic patches, which stained feebly and uniformly, and were free from cells and lacunæ. The microscopic diagnosis was therefore given as chondrosarcoma.

VI. All the foregoing cases were men. The sixth case was a woman aged 36 , who was under the care of Prof. Senator, and died in October, 1897 (12). She suffered from severe pains in the chest and back, and paralysis of one of the hypoglossal nerves. No deformi- 
ties appear to have been noticed, and the diagnosis was nephritis with albumosuria. The post-mortem showed the presence of a new formation in several of the ribs, proceeding from the medulla and regarded as a myelogenous round-celled sarcoma. The kidneys were amyloid.

A case reported by Noël Paton and Byrom Bramwell was at one time believed by Prof. Huppert to belong to this class. In the former paper the author (Dr. Bradshaw) expressed doubts as to the correctness of this view, and quite lately Prof: Huppert has abandoned it (13).

In all these six cases the condition of the bones was either altogether overlooked during life, or was considered to be osteomalacia. In Kühne's the absence of an autopsy leaves us in some doubt as to the actual condition of the bones, but it was probably the same as in the others.

It thus appears that our case is the first published case of albumosuria in which the diagncsis of multiple bone tumour was made during life; and further, that it is the first case in which the diagnosis made during life has been confirmed by the post-mortem examination.

Quite recently one of us (T. R. B.) has been informed by Dr. Reginald H. Fitz of Boston of another case not yet published, in which the diagnosis was made during life and confirmed by the autopsy. A brief reference to this case will be found in a paper read before the Association of American Physicians last May (14).

The records of the six cases we have given in detail show a general resemblance in their morbid anatomy, and this resemblance is shared by the case we have described ourselves. The appearances are by no means identical, and we find in the records of cases where no albumosuria was observed, descriptions of microscopical appearances indistinguishable from those described in the records of the cases we have quoted (15). This is perhaps to be expected, since round-celled formations may undergo various degrees of evolution, as we 
observe taking place in various kinds of sarcoma. It seems to us that the mere microscopical characters of the growths do not by themselves form any sound basis of classification, but we maintain that in spite of their observed differences in structure the occurrence of albumosuria entitles these cases to be placed in a category by themselves.

That a morbid process taking place in a region remote trom the kidneys should be associated with the presence in the urine for a long period of large quantities of a substance which it does not contain in any other circumstances, is a rare event in pathology. The presence, however, in such a condition of a substance not only foreign to normal urine, but unknown to the pathological chemist in any other connection, is probably without a parallel. The most obvious analogy, though it is only a remote one, is the occurrence of sugar in the urine in association with disease of the pancreas, but in that case we have only to deal with a familiar chemical substance which is known to take part in the normal metabolism of the body. The occurrence of the albumose cannot be looked upon as an accident; when it is found at all it is present for months or even years, and persists until the close of the case. We venture, therefore, to maintain that cases of bone disease with albumosuria must be placed in a different category from those in which this symptom does not occur; that albumosuria with bone disease is a distinct pathological entity, which is probably as far removed from other forms of multiple myeloma as the latter are from osteomalacia. If this be granted, it is desirable to give a name to the condition which will serve to mark its identity; and we offer the term Myelopathic Albumosuria as one which expresses the leading features of the disorder without implying the acceptance of any debatable theories as to its nature.

We may be permitted to recall the fact that we owe the earliest recognition of this disease to a Fellow of the Royal Medical and Chirurgical Society, and that it was 
before this Society that the completed record of the first case was laid. Half a century elapsed before its occurrence was observed again in any part of the British dominions, and it seemed appropriate that when the second case appeared it should also be communicated to this Society. But though history repeats itself, it never repeats itself exactly, and while the case presented fifty years ago was the first observed, the case which has been presented now is the first in which a correct diagnosis has been made during life and confirmed by examination after death. We venture to express the hope that the association of the Society with the clinical history and the pathology of this remarkable disorder will not end here, but that before the next half-century has passed away one of the Fellows may be in the position to point out the causes which give rise to myelopathic albumosuria, and perhaps to indicate some means of arresting its course.

\section{References.}

1. Bradshaw, T. R.-A Case of Albumosuria in which the Albumose was spontaneously precipitated. Med.-Chir. Trans., 1898, p. 259.

2. Bence Jones.-On a New Substance occurring in the Urine of a Patient with Mollities Ossium. Phil. Trans. of the Royal Society, 1848.

3. von Rustizkr, J.-Multiples Myelom. Deutsch. Zeitschr. f. Chirurgie, Band iii, s. 163, 1873.

4. Specimens preserved in the Pathological Museum of University College, Liverpool.

5. Macintyre, William.-Case of Mollities and Fragi. litas Ossium accompanied with Uline strongly charged with Animal Matter. Med.-Chir. Trans., 1850, p. 211. Bence-Jones, loc. cit.

6. Dalrymple, John.-On the Microscopical Character of Mollities Ossium. Dublin Quarterly Journ. of Med. Sci., 1846, p. 85.

vOL. LXXXII. 
7. KüHNe, W.-Ueber Albumose im Harne. Zeitschr. f. Biolog., N. F., Bd. i, 1883, s. 210.

8. KaHLER, O.-Zur Symptomatologie des Multiplen Myeloms : Beobachtung von Albumosurie. Prager med. Wochenschrift, 1889, N. 4, 5. H. HuPPERT, Ein Fall von Albumosurie, ibid.

9. ZeEhuisen.-Ueber Hemialbumosurie. Jahresber. $f$. Thier-Chem., Bd. xxi, s. 412 ; Bd. xxii, s. 525 ; and Bd. xxiii, s. 577 .

10. Seegelken.-Ueber Multiples Myelom und Stoffwechseluntersuchungen bei derselben. Deutsch. Archiv f. klin. Med., Bd. lviii, 1897, s. 276.

11. Matrites, M.-Ueber Eiweiss-Körper im Urine bei Osteomalacie. Verhandl. des Congress. f. innere Med., xix. Neumeisier, Lehrbuch der phys. Chem., Aufl. ii, 1897, s. 804.

12. Rosin.-Ueber einen eigenartigen Eiweiss-Körper im Harne, \&c. Berliner klin. Woch., 1897, No. 48.

13. HUPPER'.-Ueber den Noël-Paton'schen EiweissKörper. Centralb. f. d. med. Wissensch., 1898, No. 28. 14. Fitz, R. H.-The Significance of Albumosuria in Medical Practice, \&c. Amer. Journ. of the Med. Sciences, July, 1898, p. 30.

15. Weber, F. Parkes.-General Lymphadenomatosis of Bones, \&c. Journ. of Path. and Bact., January, 1898.

(For' report of the discussion on this paper, see 'Proceedings of the Royal Medical and Chirurgical Society,' Third Series, vol. xi, p. 81.) 